\title{
Comparative Study on the Dynamics of Rhizosphere and Non Rhizosphere Soil
}

\author{
B. Aparna ${ }^{1^{*}}$, R. Gladis ${ }^{1}$, Biju Joseph ${ }^{2}$ and Neethu R.Sathyan ${ }^{1}$ \\ ${ }^{1}$ Dept of Soil science and Agrl Chemistry, College of Agriculture, Vellayani-695522, India \\ ${ }^{2}$ Instructional Farm, Vellayani-695522, India \\ *Corresponding author
}

\begin{abstract}
A B S T R A C T
A study was carried out in the Department of Soil Science and Agrl Chemitry, College of Agriculture, Vellayani, Kerala Agricultural University to compare the respiratory and microbial activities under integrated plant nutrient system between rhizosphere and non rhizosphere in laterite soil under Integrated Plant Nutrient System. The rhizosphere and non rhizopshere samples of the test crop Okra were collected and analysed for microbial parameters and respiratory activity. The fertility index (Enzyme activity numbe) was also worked out.Microbial count was calculated using serial dilution technique. For bacteria in the rhizosphere soil, $\mathrm{T}_{8}(\mathrm{P}(50 \%)$ as PSB enriched vermicompost $+\mathrm{P}(50 \%), \mathrm{N} \& \mathrm{~K})$ recorded the maximum bacterial count while in the non- rhizosphere soil, highest value of bacterial colonies was recorded by $\mathrm{T}_{12}(\mathrm{P}(75 \%)$ as $\mathrm{PSB}$ enriched vermicompost $+\mathrm{P}$ (25\%), N \& K). Treatment $\mathrm{T}_{9}$ (NPK (50\%), PGPR mix-1 enriched vermicompost + N, P $\& \mathrm{~K}(50 \%)$ recorded maximum number of fungal colonies in rhizosphere soil and actinomycetes in the non rhizosphere soil. In the non rhizosphere soil, maximum number of fungal colonies was observed with the application of $\mathrm{T}_{9}$ and $\mathrm{T}_{13}$. Treatment $\mathrm{T}_{13}(\mathrm{~N}, \mathrm{P}, \mathrm{K}$, $(75 \%)$ as PGPR mix-1 enriched vermicompost $+\mathrm{N}, \mathrm{P} \& \mathrm{~K}(25 \%)$ recorded the highest values for actinomycetes in the rhizosphere soil. The enzyme activity number is found to be higher than the rhizosphere soil.It is understood that rhizosphere, the soil adjacent to plant roots is significantly different from bulk soil in chemical, biological and microbiological properties
\end{abstract}

\section{Introduction}

Soil fertility and crop production are affected by biological and chemical processes which are intimately involved in the cycling of nutrients, effect fertilizer use efficiency, reflect the microbiological activity in soil and act as indicators of soil productivity. As soil is a part of terrestrial environment and supports all terrestrial life form, protection of soil is therefore of high priority and thorough understanding of soil physical and biological activities is a critical factor in assuring that the soil remains healthy.

Soil microbial communities in the rhizosphere are the most important functional component of soil biota playing a key role in energy 
flows and nutrient reactions (Tate, 2000). Root-colonizing plant beneficial bacteria, commonly referred to as plant growthpromoting rhizobacteria (PGPR), are capable of stimulating plant growth when cultivated in association with a host plant. PGPR are able to increase plant growth, accelerate seed germination, improve seedling emergence responses to external stress factors, protect plants from disease, and promote root growth (Kennedy, 1998).

The balanced fertilization of major elements (NPK) for plant nutrient could be beneficial for the growth of plant above ground parts and roots. However farmers are often forced to make decision about their fertilization strategy that reflects economic rather than agronomic pressure. When economic pressure is lifted, nitrogen and to a lesser extent, phosphorous are the nutrients of choice and the need for potassium is either under estimated or ignored. As a result imbalanced fertilization is still widespread.

Hence the concept of Integrated Plant Nutrient System (IPNS) encompassing adequate and balanced use of nutrients in an integrated manner employing chemical, organic and biofertilizers is the most ideal system of nutrient management. IPNS is a concept and farm management strategy which embraces and transcends from single crop fertilization effects to planning and management of plant nutrients in crop rotation and farming systems on long term basis for enhanced productivity, profitability and sustainability. The primary goal of integrated nutrient management is to combine old and new methods of nutrient management into ecologically sound and economically viable farming systems that utilize available organic and inorganic sources of nutrients in a judicious and efficient way (Acharya et al., 1998). To avoid the side effects of fertilizers and to provide socioeconomic and ecological benefits, biofertilizers are generally recommended. Biofertilizers contains living micro organisms and it is expected that their activities will influence the soil ecosystem and produce supplementary substance for the plants. The region and crop- specific consortia of biofertilizers (combining Azotobacter, Azospirillum, Phosphate solubilising bacteria, Rhizobium and Plant Growth Promoting Rhizobacteria) should be developed. There is a thus dire need to popularize the technology of integrating these bioinoculants with inorganics by the way of substitution which can be achieved through IPNS. Hitherto the present investigation was undertaken to study the effect of integrated plant nutrient system (IPNS) on the dynamics of rhizosphere and non rhizosphere soils.

\section{Materials and Methods}

The present study entitled Study on the dynamics of rhizosphere and non rhizophere soil was carried out in the Department of Soil Science and Agrl. Chemistry at College of Agriculture, Vellayani during March- June 2012. The soil of the experimental site was sandy clay loam belonging to the family of Loamy Kaolinitic Isohypothermic Typic Haplustalf. The test crop used for the study is Bhindi variety "Varsha Upahar", a green fruited variety suitable to southern Kerala having duration of 105 days.

Enrichment of vermicompost was carried out using Azospirillum, Phosphorus solubilizing bacteria, PGPR mix-1 at the rate of $2 \%$. Other source of enrichment used was Neemcake@ $0 \%$.

The nutrient content in the enriched composts were analysed and were applied to the crop to meet the nutrient requirement in specific doses. The rest of the crop requirement was supplemented by the addition of inorganic fertilizers. Enriched vermicompost were 
analysed for major nutrients using standard analytical procedures and data are presented in Table 1.

Various combinations of enriched vermicompost with inorganics was used for the study. Rhizosphere soils were collected by the method of destructive sampling of the plants. Plants were uprooted and the rhizosphere soils were collected in polythene bags. These soils were stored in deep freezers to ensure the viability of microorganisms.

Non rhizosphere soils were collected from the non-rhizosphere areas and stored as above. Soil for chemical analysis were collected, dried in shade, powdered with a wooden mallet, sieved through a $2 \mathrm{~mm}$ sieve and stored in polythene containers. The respiratory activity of the soil samples were estimated using the method outlined by Jenkinson and Powlson (1976), where the $\mathrm{CO}_{2}$ evolved from a fixed quantity of incubated soil was collected in an alkali and quantified. The initial data on physical, chemical and biological properties of the soil where field experiment was conducted are given below in Table 2 .

Microbial count in the soil was enumerated using serial dilution technique proposed by Timonin (1940). Composition of the media was presented in Table 3.

The data generated from these experiments were subjected to the analysis of variance as per the design and their significance was tested by the F test (Snedecor and Cochran, 1975).

\section{Results and Discussion}

Soil microbial populations are immersed in a framework of interactions known to affect plant fitness and soil quality. They are involved in fundamental activities that ensure the stability and productivity of both agricultural systems and natural ecosystems. A comparison of respiratory and microbial activities under integrated plant nutrient system between rhizosphere and non rhizosphere was attempted in this study. The differing physical, chemical, and biological properties of the root-associated soil, compared with those of the root-free bulk soil, are responsible for changes in microbial diversity and for increased number and activity of micro-organisms in the rhizosphere micro-environment (Kennedy, 1998).

Microbial count was calculated using serial dilution technique. For bacteria in the rhizosphere soil, $\mathrm{T}_{8}(\mathrm{P} \quad(50 \%)$ as PSB enriched vermicompost $+\mathrm{P}(50 \%), \mathrm{N} \& \mathrm{~K})$ recorded the maximum bacterial count (184.67 $\times 10^{6} \mathrm{CFU} \mathrm{g}^{-1}$ of soil) while in the nonrhizosphere soil, highest value of bacterial colonies was recorded by $\mathrm{T}_{12}(\mathrm{P}(75 \%)$ as $\mathrm{PSB}$ enriched vermicompost $+\mathrm{P}(25 \%), \mathrm{N} \& \mathrm{~K})$. In the rhizosphere soil, the significant effect of treatments on soil bacteria was observed (Fig. 1). It is quite interesting to note that treatment involving the application of $50 \%$ of $\mathrm{P}$ as Phosphate solubilizing bacteria enriched vermicompost along with inorganics was similar in effect with $50 \%$ of NPK as PGPR mix-1 enriched vermicompost in combination with inorganics. This might be due to the positive co-operation between PGPR and PSB thus contributing to higher activity of bacteria. In the non rhizosphere soil, application of bio inoculants has significantly increased the bacterial count.

In the rhizosphere soil, fungi population was higher in bio inoculants treated soils in the rhizosphere zone than the non rhizosphere soil (Fig. 2).From the study it was observed that treatment $\mathrm{T}_{9}$ (NPK (50\%), PGPR mix-1 enriched vermicompost $+\mathrm{N}, \mathrm{P} \& \mathrm{~K}(50 \%)$ recorded maximum number of fungal colonies in rhizosphere soil $\left(13.67 \times 10^{4} \mathrm{CFU} \mathrm{g}{ }^{-1}\right)$ and 
actinomycetes in the rhizosphere soil ( 9.33 $\mathrm{x} 10^{4} \mathrm{CFU} \mathrm{\textrm {g } ^ { - 1 }}$ of soil). In general the maximum number of funagal colonies was found to be higher in rhizosphere soil than the non rhizosphere soil. In the non rhizosphere soil, maximum number of fungal colonies was observed with the application of $\mathrm{T}_{9}$ and $\mathrm{T}_{13}$ $\left(8.67 \times 10^{4} \mathrm{CFU} \mathrm{g}^{-1}\right)$.

It is inferred from the Fig. 3 that the actinomycetes population had varied significantly with treatments in both rhizosphere and non-rhizosphere soils. Application of PGPR mix-1enriched vermicompost had increased the actinomycetes population in both the soils. Treatment $\mathrm{T}_{13}(\mathrm{~N}, \mathrm{P}, \mathrm{K},(75 \%)$ as PGPR mix1 enriched vermicompost $+\mathrm{N}, \mathrm{P} \& \mathrm{~K}(25 \%)$ recorded the highest values for actinomycetes in the rhizosphere soil which was higher than the non rhizosphere soil.

The rhizosphere, the zone of soil under the influence of root is characterized by high microbial diversity, activity, number of organisms and complex interactions and root (Oger et al., 2004). The population and functions of microorganisms cannot be overlooked while considering soil health because microorganisms provide living environment to the soil and perform various functions. It has been recently postulated that an additional mechanism for plant growth promotion by PGPR could be their altering of microbial rhizosphere communities (Ramos et al., 2003).

The higher activity of microflora as a whole in the rhizosphere soil over the nonrhizosphere soil might be attributed to the microbial colonization in the rhizosphere known as root colonization. Since the rhizosphere is considered as the most intense ecological habitat in soil, it is of interest to study the effects that PGPR may have on total microbial activity and bacterial population where rhizobacteria exerted a direct influence on plants (Jeffries et al., 2003; Aroca and Ruiz-Lozano 2009).

Soil enzymes have been suggested as potential indicators of soil quality because of their essential role in soil biology. Ease of measurement and rapid response to changes in soil management (Dick et al., 1994). Enzyme activity number is an index of biological fertility. Treatment $\mathrm{T}_{9}$ with the application of NPK 50\% as PGPR mix- 1 enriched vermicompost in combination with inorganics reported the highest value for enzyme activity number in the rhizosphere zone indicating the effect of the treatment in sustaining the soil biological health. Similar results were reported by Riffaldi et al., (2002) who reported higher enzyme activity number in untilled management system than the tilled management system.

Table.1 Details of enrichment of vermicompost

\begin{tabular}{|l|l|c|c|c|}
\hline Enriched Vermicompost & Rate & $\mathbf{N}(\boldsymbol{\%})$ & $\mathbf{P}_{\mathbf{2}} \mathbf{O}_{\mathbf{5}}(\mathbf{\%})$ & $\mathbf{K}_{\mathbf{2}} \mathbf{O}(\mathbf{\%})$ \\
\hline Neemcake & @ 5\% & 4.1 & 0.7 & 1.4 \\
\hline Azospirillum & @ 2\% & 4.7 & 0.7 & 0.5 \\
\hline PSB & @ 2\% & 1.5 & 1.8 & 0.5 \\
\hline PGPR mix-1 & @ 2\% & 1.5 & 1.8 & 1.9 \\
\hline
\end{tabular}


Table.2 Microbial properties of initial soil sample

\begin{tabular}{|l|l|l|l|}
\hline $\mathbf{1}$ & \multicolumn{2}{|l|}{$\begin{array}{l}\text { Soil respiratory activity }\left(\boldsymbol{\mu g} \text { of } \mathrm{CO}_{2}\right. \\
\left.\text { evolved } \mathbf{g}^{-1} \text { of soil } \mathbf{~ h r}^{-1}\right)\end{array}$} & $\mathbf{2 . 8}$ \\
\hline $\mathbf{2}$ & Micro flora & Bacteria & $42 \times 10^{6} \mathrm{CFU} \mathrm{g}^{-1}$ soil \\
\hline & Fungi & $2 \times 10^{4} \mathrm{CFU} \mathrm{g}^{-1}$ soil \\
\hline & Actinomycetes & 0 \\
\hline
\end{tabular}

Table.3 Composition of media

\begin{tabular}{|l|l|l|}
\hline Sl No. & Microflora & Medium \\
\hline $\mathbf{1}$ & Actinomycetes & Ken knight's agar medium \\
\hline $\mathbf{2}$ & Fungi & Martins' Rose Bengal agar \\
\hline $\mathbf{3}$ & Bacteria & Nutrient agar \\
\hline
\end{tabular}

Table.4 Enzyme activity number ( Biological Fertility Index) of the Rhizosphere soil

\begin{tabular}{|c|c|c|c|c|c|c|}
\hline Treatments & 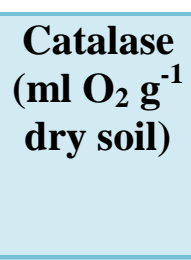 & $\begin{array}{l}\text { Phosphate } \mu \mathrm{g} \\
\text { of p- } \\
\text { nitrophenol } \\
\text { released } \mathrm{g}^{-1} \text { of } \\
\text { soil } \mathbf{h r}^{-1}\end{array}$ & $\begin{array}{l}\text { Protease }(\mu \mathrm{M} \\
\text { of amino } \mathrm{N}- \\
\text { hydrolysed } \mathbf{g}^{-1} \\
\left.\text { of soil } \mathbf{h r} \mathbf{r}^{-1}\right)\end{array}$ & $\begin{array}{l}\text { Dehydrogenase } \\
(\mu \mathrm{g} \text { of TPF } \\
\text { hydrolysed } \mathrm{g}^{-1} \text { of } \\
\text { soil per } 24 \mathrm{hrs})\end{array}$ & $\begin{array}{c}\text { Cellulase } \\
\text { (glucose } \\
\text { hydrolysed } \mathbf{g}^{-1} \\
\text { of soil } \\
24 \mathrm{hrs}^{-1} \text { ) }\end{array}$ & $\begin{array}{l}\text { Enzyme } \\
\text { activity } \\
\text { number }\end{array}$ \\
\hline$T_{1}$ & 2.47 & 47.53 & 140.75 & 158.51 & 29.24 & 32.64 \\
\hline $\mathbf{T}_{2}$ & 3.15 & 48.83 & 148.31 & 162.82 & 33.08 & 33.54 \\
\hline$T_{3}$ & 3.47 & 49.93 & 154.44 & 165.46 & 35.31 & 34.11 \\
\hline$T_{4}$ & 7.00 & 63.71 & 157.74 & 203.86 & 38.30 & 41.88 \\
\hline$T_{5}$ & 7.01 & 59.46 & 149.5 & 185.09 & 40.35 & 38.06 \\
\hline $\mathbf{T}_{6}$ & 6.14 & 62.12 & 163.13 & 183.01 & 42.21 & 37.73 \\
\hline $\mathbf{T}_{7}$ & 6.37 & 62.22 & 163.73 & 188.49 & 43.59 & 38.79 \\
\hline$T_{8}$ & 6.91 & 79.67 & 175.49 & 188.32 & 44.13 & 38.97 \\
\hline$T_{9}$ & 8.27 & 75.33 & 181.13 & 227.79 & 49.83 & 46.84 \\
\hline$T_{10}$ & 7.21 & 51.7 & 160.76 & 205.32 & 38.81 & 42.12 \\
\hline$T_{11}$ & 7.12 & 53.54 & 170.82 & 208.83 & 42.84 & 42.89 \\
\hline$T_{12}$ & 7.30 & 68.56 & 173.53 & 218.63 & 43.37 & 44.93 \\
\hline$T_{13}$ & 8.13 & 67.57 & 176.38 & 220.38 & 45.87 & 45.29 \\
\hline$T_{14}$ & 2.47 & 40.46 & 141.08 & 132.44 & 26.79 & 27.39 \\
\hline $\mathbf{T}_{15}$ & 1.57 & 39.46 & 101.45 & 127.18 & 25.79 & 26.14 \\
\hline
\end{tabular}


Fig.1 Bacterial population in post harvest soil samples

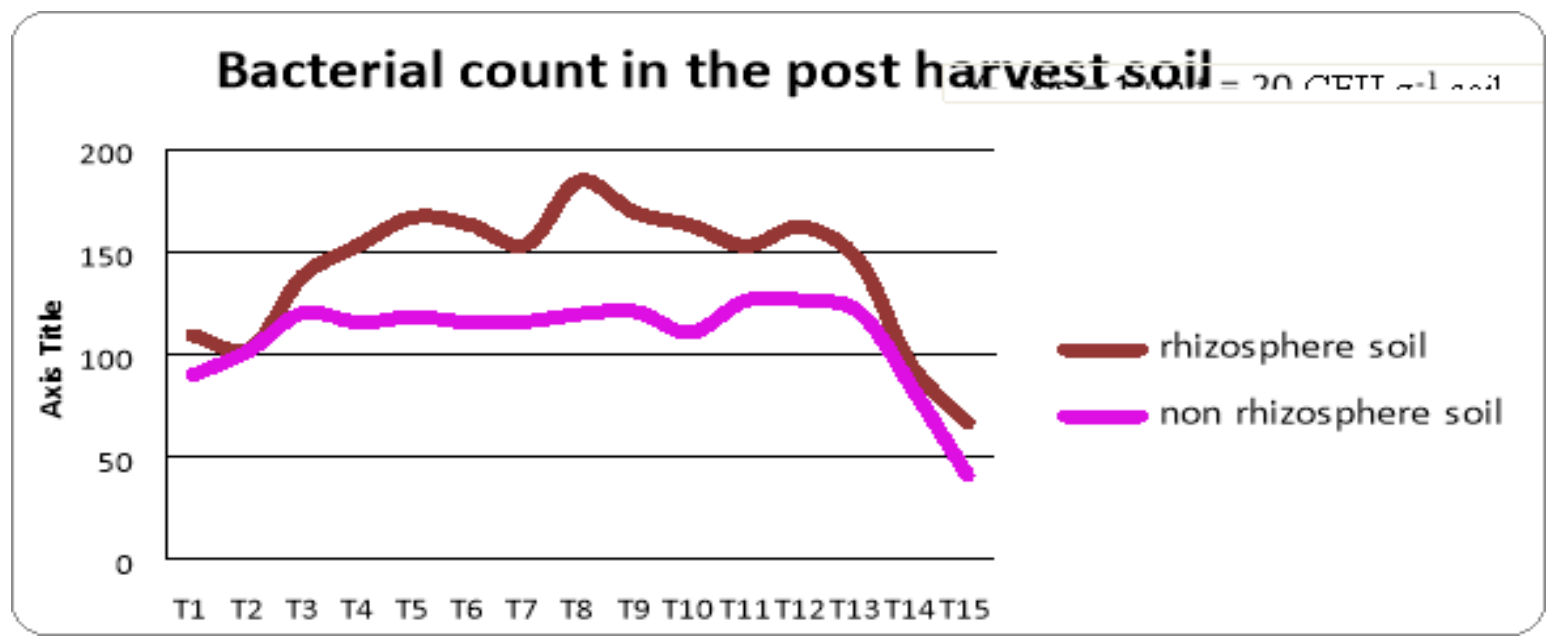

Fig.2 Fungal population in post harvest soil

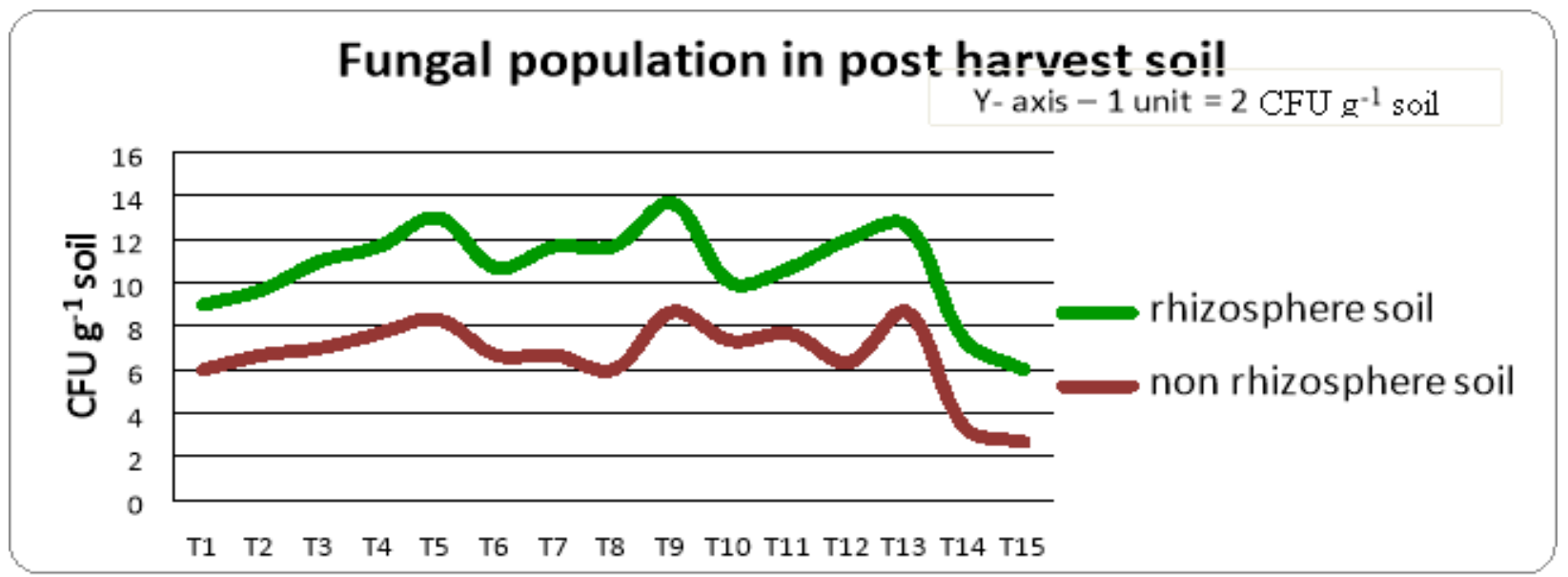

Fig.3 Actinomycetes in post harvest soil

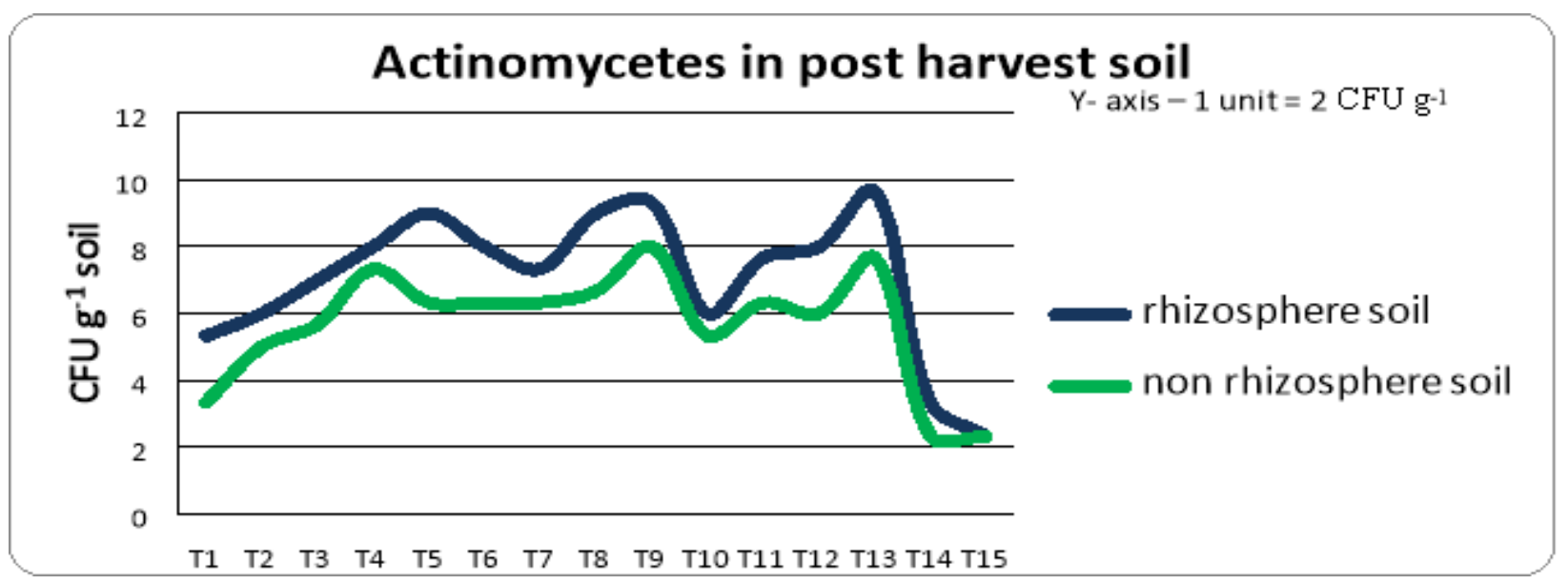


Fig.4 Enzyme activity number of Rhizosphere soil

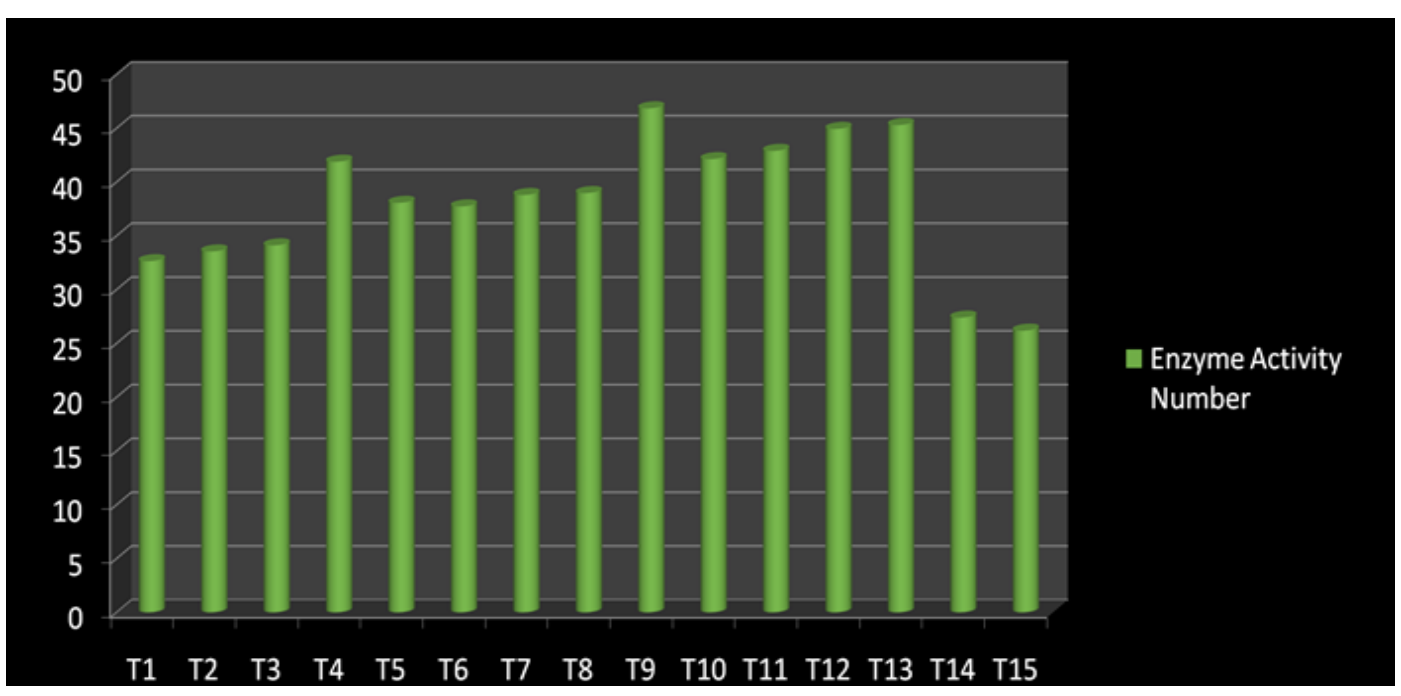

Fig.5 Soil respiratory activity in rhizosphere soil

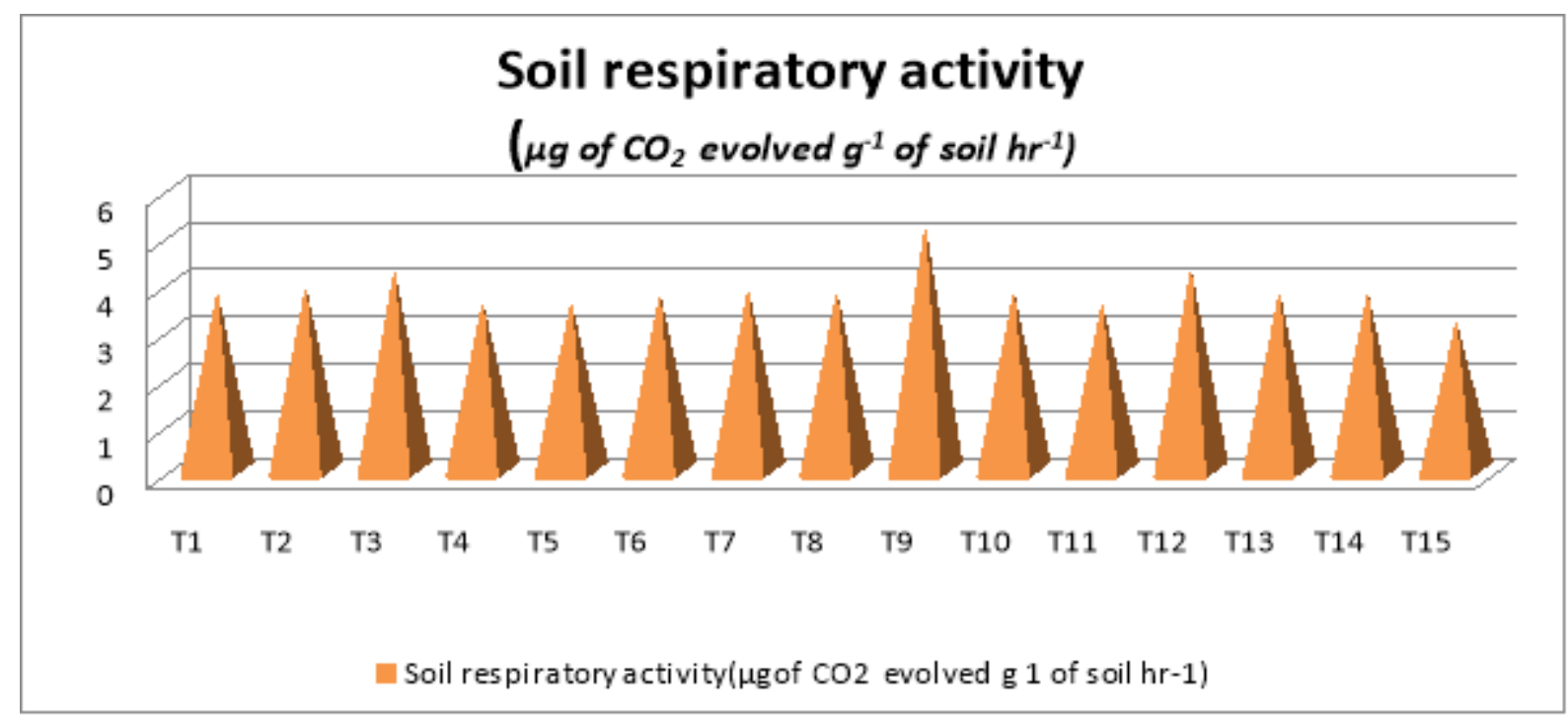

Respiratory activity of soil belongs among the most important characteristics of the soil biological activity (Iovieno et al., (2009). Usually measured as $\mathrm{CO}_{2}$ emissions (in laboratory or in situ), it is a strong indicator of the soil metabolism and ecological soil functions (Santruckova, 1993). It is inferred from the Fig. 4., treatments receiving $75 \%$ of $\mathrm{P}$ as PSB enriched vermicompost in combination with inorganics and $25 \%$ of $\mathrm{N}$ as Azospirillum enriched vermicompost in combination with inorganics had registered highest values for soil respiratory activity. It might be due to the fact that organic fertilisation contributes to the soil organic matter accumulation and turnover (Kubát et al., 1999). Raupp and Lockretz (1997) reported that an increased soil organic matter accumulation and turnover enhanced respiration activity in rhizosphere soils.

It is understood that rhizosphere, the soil adjacent to plant roots is significantly different from bulk soil in chemical, biological and microbiological properties. The 
rhizosphere is the zone of soil influenced by roots through the release of substrates that affect microbial diversity and activity.

These microbes are responsible for key environmental processes, such as biogeochemical cycling of nutrients and matter and the maintenance of plant health and soil quality (Barea et al., 2004). In particular, the varied genetic and functional activities of the extensive microbial populations have a critical impact on soil functions, based on the fact that microorganisms are driving forces for fundamental metabolic processes involving specific enzyme activities (Nannipieri et al., 2003). These factors have contributed to the increased microbial activities in rhizosphere.

From the study it is concluded that certain bacteria, fungi and actinomycetes are able to colonize the root soil environment where they carry out a variety of interactive activities known to benefit plant growth and health and soil quality. An increased respiratory activity was also noticed in the rhizoshere zone than the non rhizosphere zone. Under integrated plant nutrient system, it is clearly evident that the microflora was more in rhizosphere than in the non rhizosphere.

\section{References}

Acharya, C. L., Tomar, K. P., Rao, A.S., Ganguly, T. K., Singh, M.V., Rao, D. L. N., Rao, C. H. S. and Rupa, T. R. 1998. Integrated Plant Nutrient Supply System for sustainable agriculture. Indian Institute of Soil Science, Bhopal.

Aroca, R. and Ruiz-Lascano, J.M. 2009. Induction of plant tolerance to semi-arid environments by beneficial soil microorganisms - a review. Sustain. Agric. Rev. 2:121-135

Barea, J.M., Azcon, R. and Azcon-Aguilar, C. 2004. Mycorrhizal fungi and plant growth promoting rhizobacteria. In: Varma, A., Abbott, L., Werner, D. and Hampp, R. (eds). Pl. Surf. Microbiol. Heidelberg, Germany: Springer-Verlag, 351-371.

Dick, R. P., Sandor, J. A. and Eash, N. S. 1994. Soil enzyme activities after 1500 years of terrace agriculture in the Colca Valley, Peru. Agric. Ecosyst. Environ. 50: 123-131

Iovieno, P., Morra, L., Leone, A., Pagano, L. and Alfani, A. 2009. Effect of organic and mineral fertilizers on soil respiration and enzyme activities of two Mediterranean horticultural soils. Biol. Fertil. Soils. 45:555-561

Jeffries, P., Gianinazzi, S.,Perotto, S., Turnau, K. and Barea, J. M. 2003. The contribution of arbuscular mycorrhizal fungi in sustainable maintenance of plant health and soil fertility. Biol. Fert. Soils. 37:1-16

Jenkinson, D. S. and Powlson, D. S. 1976. The effect of biocidal treatments on metabolism of soil $-\mathrm{V}$. A method for measuring soil biomass. Soil Biol. Biochem. 8: 209-213

Kennedy, A. C. 1998. The rhizosphere and spermosphere. In: Sylvia, D. M., Fuhrmann, J.J., Hartel, P. G. and Zuberer, D. A. (eds.). Principles and applications of soil microbiology. Upper Saddle River, New Jersey: Prentice Hall, 389-407

Kubat, J., Novakova, J., Mikanov, O. and Apfelthaler, R. 1999. Organic carbon cycle, incidence of microorganisms and respiration activity in long-term field experiment. Rostl. Vyr. 9: 389-395.

Nannipieri, P., Ascher, J., Ceccherini, M. T., Landi, L., Pietramellara, G. and Renella, G. 2003. Microbial diversity and soil functions. Eur. J. Soil Sci., 54, 655-667

Oger , P. M., Mansouri, H., Nesme, X. and Dessaux, Y. 2004. Engineering root 
exudation of Lotus toward the production of two novel carbon compounds leads to the selection of distinct microbial populations in the rhizosphere. Microbial Ecol.47: 96103.

Ramos, B., Garcia, J. A. L., Probanza, A., Barrientos, M. L. and Mañero, F. J. G. 2003. Alterations in the rhizobacterial community associated with European alder growth when inoculated with PGPR strain Bacillus licheniformis. Environ. Exp. Bot. 49:61-68.

Raupp, J. and Lockeretz, W. 1997. Yield, product quality and soil life after longterm organic or mineral fertilization. In: Proc. Int. Conf. Agricultural production and nutrition, Boston, Massachusetts, USA: $91-101$.
Riffaldi, R., Saviozzi, A., Levi-Minzi, R. and Cardelli, R. 2002. Biochemical properties of a Mediterranean soil as affected by long term crop management systems. Soil Tillage Res. 67:109-114.

Santruckova, H. 1993. Respiration activity of soil as a criterion of its biological activity. Rostl. Výr., 39: 769-778. (In Czech)

Snedecor, G. W. and Cohran, W. G. 1975. Statistical methods. Oxford and IBH Publishing Company, New Delhi, 593p.

Timonin, M. J. 1940. The interaction of higher plants and soil microorganismsmicrobial population of rhizosphere of seedlings of certain cultivated plants. Can. J. Res. 181: 307-317.

\section{How to cite this article:}

Aparna, B., R. Gladis, Biju Joseph and Neethu R. Sathyan. 2020. Comparative Study on the Dynamics of Rhizosphere and Non Rhizosphere Soil. Int.J.Curr.Microbiol.App.Sci. 9(06): 2527-2535. doi: https://doi.org/10.20546/ijcmas.2020.906.307 